Економічні науки: збірник наукових прачь Луиького національного технічного університету. Серія "Регіональна економіка". Випуск 17 (67). Редкол.: відп. ред. к.е.н., професор І.В. Кривов’язюк. Луцьк: ІВВ Луцького НТУ, 2020. 348 с.

УДК 332.33:631.1

Московчук А.Т., к.е.н., доцент

Ліщук М.Є., к.с.-г.н., доцент

Луцький національний технічний університет

\title{
ОЦІНКА ТА ПЕРСПЕКТИВИ ВИКОРИСТАННЯ СІЛЬСЬКОГОСПОДАРСЬКИХ УГІДЬ У ВОЛИНСЬКІЙ ОБЛАСТІ
}

У статті охарактеризовано динаміку і структуру сільськогосподарських угідь Волинської області та України. Визначено основні фактори впливу на валовий збір зернових, зернобобових та олійних культур. Використано індексний метод розрахунку впливу площі та урожайності на валовий збір. Окреслено перспективні напрями використання сільськогосподарських угідь, які забезпечать перехід сільського господарства на інтенсивний шлях розвитку.

Ключові слова: сільське господарство, сільськогосподарські угіддя, сільськогосподарські культури, зібрана площа, урожайність, валовий збір, індексний метод.

\section{Moskovchuk A., Lishchuk M. ASSESSMENT AND PROSPECTS OF USE OF AGRICULTURAL LAND IN VOLYN REGION}

For the rational use of agricultural land it is necessary to ensure optimization of the structure of sown areas, introduction of scientifically sound crop rotations, multifunctionality of agriculture, as well as it is useful to take into account the regional features of agriculture.

$64,2 \%$ of agricultural land in Volyn region is represented by arable land. This structure of agricultural land is not optimal. The share of arable land is much higher compared to scientifically substantiated recommendations. It is advised in these recommendations that not more than a third of agricultural land should be used in active agricultural cultivation.

A comparative analysis of the volume of production of major crops in the Volyn region showed a gradual increase in gross harvest of some types of crops and a decrease in others. Factor analysis of the gross harvest of cereals and legumes and oilseeds in the region allows us to conclude that its growth is due to the predominant increase in sown area. This indicates that agricultural land in the Volyn region is used extensively. 
Економічні науки: збірник наукових прачь Луиького національного технічного університету. Серія "Регіональна економіка". Випуск 17 (67). Редкол.: відп. ред. к.е.н., професор І.В. Кривов’язюк. Луцьк: ІВВ Луцького НТУ, 2020. 348 с.

The growth of the gross harvest of agricultural crops is to be ensured through the growth of productivity, ie through transition to intensive path of agricultural development.

Key words: agriculture, agricultural lands, agricultural crops, harvested area, yield, gross harvest, index method.

Московчук А., Лищук М.

\section{ОЦЕНКА И ПЕРСПЕКТИВЫ ИСПОЛЬЗОВАНИЯ СЕЛЬСКОХОЗЯЙСТВЕННЫХ УГОДИЙ В ВОЛЫНСКОЙ ОБЛАСТИ}

В статье охарактеризованы динамика и структура сельскохозяйственных угодий Волынской области и Украины. Определены основные факторы влияния на валовой сбор зерновых, зернобобовых и масличных культур. Использован индексный метод расчета влияния площади и урожайности на валовой сбор. Определены перспективные направления использования сельскохозяйственных угодий, которые обеспечат переход сельского хозяйства на интенсивный путь развития.

Ключевые слова: сельское хозяйство, сельскохозяйственные угодья, сельскохозяйственные культуры, собранная площадь, урожайность, валовой сбор, индексный метод.

Постановка проблеми у загальному вигляді та її зв'язок із важливими науковими чи практичними завданнями. Аграрний сектор посідає важливе місце в економіці України та формує левову частку іiі експортного потенціалу. У 2019 р. його внесок у ВВП країни (за виробничим методом) становив 9\% і це третє місце серед інших секторів економіки [1]. Він, як і решта сфер економіки, потребує змін та створення конкурентних умов в усіх його складниках, зокрема у сільському господарстві.

3 прийняттям Закону України «Про внесення змін до деяких законодавчих актів України щодо обігу земель сільськогосподарського призначення» розпочався, хоча i неоднозначний, процес формування ринкового конкурентного середовища у фундаментальній ланці сільського господарства створення ринку земель (купівлі-продажу) сільськогосподарського призначення. Проте конкурентний ринковий механізм може сприяти ефективній діяльності в 
Економічні науки: збірник наукових прачь Луиького національного технічного університету. Серія "Регіональна економіка". Випуск 17 (67). Редкол.: відп. ред. к.е.н., професор І.В. Кривов'язюк. Луиьк: ІВВ Луцького НТУ, 2020. 348 с.

сільському господарстві лише за умови його сталого розвитку через врахування комплексу економічних, соціальних та екологічних чинників.

Раціональне використання сільськогосподарських угідь передбачає реалізацію комплексу взаємопов'язаних заходів, які у першу чергу, мають бути спрямовані на: оптимізацію структури посівних площ, запровадження науково обгрунтованих сівозмін задля підвищення родючості грунтів, забезпечення багатофункціональності сільського господарства, врахування не лише економічної доцільності, але і регіональних особливостей ведення сільського господарства тощо. У зв' язку з цим актуальною залишається проблема виявлення регіональних перекосів у використанні посівних площ та переходу на інтенсивний шлях розвитку сільського господарства, що передбачає врахування соціально-економічних та екологічних чинників.

Аналіз останніх досліджень і публікацій, в яких започатковано розв'язання даної проблеми. Різні проблеми використання сільськогосподарських земель досліджені в роботах таких науковців як: В. Будзяк, П. Гайдуцький, В. Горлачук, Б. Данилишин, Д. Добряк, С. Дорогунцов, С. Кваша, В. Кушнірук, О. Міхеєва, А. Третяк, М. Хвесик та ін. Однак, здійснення постійного моніторингу ступеня раціональності використання сільськогосподарських земель через застосування різних методів аналізу $є$ необхідним для своєчасного усунення регіональних дисбалансів, що виникають та забезпечення сталості розвитку сільського господарства.

Цілі статті. Здійснити оцінку використання сільськогосподарських угідь, виявити чинники, які можуть призвести до негативних наслідків у землекористуванні та окреслити перспективи розвитку сільського господарства Волині, як частини агропромислового комплексу.

Виклад основного матеріалу дослідження 3 повним обгрунтуванням отриманих наукових результатів. Динамічний розвиток сільського господарства спричиняє мультиплікаційний ефект для економіки країни через зростання 
Економічні науки: збірник наукових прачь Луиького національного технічного університету. Серія "Регіональна економіка". Випуск 17 (67). Редкол.: відп. ред. к.е.н., професор І.В. Кривов'язюк. Луиьк: ІВВ Луцького НТУ, 2020. 348 с.

рівня зайнятості, доходів та споживання населення, розвиток суміжних галузей (переробка сільськогосподарської продукції, виробництво техніки, добрив тощо для сільського господарства), що є важливим для Волинської області, яка посідає лише 20 місце за часткою продукції сільського господарства (2,4\% у 2019 р.) у загальному виробництві сільськогосподарської продукції України. Крім того, за виробництвом продукції рослинництва Волинська область у рейтингу 21, а продукції тваринництва - 11, що вказує на диспропорції між цими видами діяльності та необхідності більш детального аналізу окремих причин у відставанні розвитку рослинництва [2, с. 47].

Загальна площа сільськогосподарських угідь Волинської області становить 1047,5 тис га, 3 них: 672,3 тис га $(64,2 \%)-$ рілля, 201,7 тис га $(19,3 \%)$ - пасовища, 161,8 тис га $(15,4 \%)-$ сіножаті та 11,7 тис га $(1,1 \%)$ - багаторічні насадження [3].

Варто зазначити, що таку структуру сільськогосподарських угідь не можна вважати оптимальною, тому що питома вага ріллі значно перевищує науково обгрунтовані норми, згідно 3 якими в активний сільськогосподарський обробіток доцільно залучати не більше третини земель сільськогосподарського призначення. Інакше це призведе до негативних економічних та екологічних наслідків.

$\begin{array}{cccr}\text { Створення } & \text { цивілізованого } & \text { ринку } & \text { земель } \\ \text { сільськогосподарського } & \text { призначення } & \text { може } & \text { сприяти }\end{array}$
прискоренню темпів розвитку рослинництва, зокрема у Волинській області. За 2015-2019 рр. відбулося зростання валового збору зернових і зернобобових культур на 2303,5 тис ц $(121,7 \%)$ та олійних культур (соняшник, ріпак) на 1761,3 тис ц або у 2,1 разу. Натомість виробництво цукрового буряка зменшилось за весь період на 2\%, а у 2019 р. порівняно з 2018 р. - на $22,1 \%$ [2]. На зміну структури рослинництва вплинула низка зовнішньоекономічних, фінансових та інших чинників.

Важливим аспектом аналізу є визначення факторів, що впливають на валовий збір зернових, зернобобових та олійних 
Економічні науки: збірник наукових прачь Луиького національного технічного університету. Серія "Регіональна економіка". Випуск 17 (67). Редкол.: відп. ред. к.е.н., професор І.В. Кривов’язюк. Луцьк: ІВВ Луцького НТУ, 2020. 348 с.

культур, виробництво яких зростає. Для визначення міри впливу факторів був використаний індексний метод.

Приріст валового збору зернових, зернобобових та олійних культур, у першу чергу, зумовлений впливом двох факторів: зібрана площа і урожайність.

Вплив факторів на валовий збір зернових, зернобобових та олійних культур визначається за формулою:

$$
\mathrm{I}_{\mathrm{3a \Gamma}}=\sum \Pi_{1} \mathrm{y}_{1} / \sum \Pi_{0} \mathrm{y}_{0}
$$

де $\Pi_{1}, \Pi_{0}$ - зібрана площа відповідно у 2019 і 2018 pp., тис га;

$\mathrm{y}_{1}, \mathrm{y}_{0}$ - середня урожайність сільськогосподарських культур відповідно у 2019 і 2018 рр., ц.

Вихідні дані для факторного аналізу представлено у таблиці 1.

1. Вплив факторів на валовий збір зернових та зернобобових культур

Послідовність розрахунку:

Загальний індекс валового збору:

$I_{\text {zar }}=\sum \Pi_{1} y_{1} / \sum \Pi_{0} y_{0}=12926,3 / 12372,1=1,045$, тобто загальний приріст валового збору зернових і зернобобових культур становить 4,5 \%. Такий приріст обумовлений:

а) впливом зміни зібраної площі:

$\mathrm{I}_{\mathrm{B} 3 \Pi}=\sum \Pi_{1} \mathrm{y}_{0} / \Pi_{0} \mathrm{y}_{0}=298,1 * 42,2 / 293,4 * 42,2=1,017$,

б) вПливом зміни середньої урожайності:

$\mathrm{I}_{\mathrm{B} 3 \mathrm{y}}=\sum \Pi_{1} \mathrm{y}_{1} / \Pi_{1} \mathrm{y}_{0}=298,1 * 43,4 / 298,1 * 42,2=1,028$, тобто збільшення зібраної площі на 4,7 тис га забезпечило зростання валового збору на 1,7 \%, а збільшення урожайності на 1,2 ц забезпечило зростання валового збору на $2,8 \%$. 
Таблиця 1

Валовий збір сільськогосподарських культур у Волинській області

\begin{tabular}{|c|c|c|c|c|c|c|c|c|c|}
\hline \multirow{2}{*}{ Культури } & \multicolumn{3}{|c|}{ Зібрана площа, тис. га } & \multicolumn{3}{|c|}{$\begin{array}{c}\text { Урожайність, } \\
\text { ц /га }\end{array}$} & \multicolumn{3}{|c|}{ Валовий збір, тис. ц } \\
\hline & $\begin{array}{c}2018 \\
\text { рік }\end{array}$ & $\begin{array}{c}2019 \\
\text { рік }\end{array}$ & $\begin{array}{c}2019 \text { p. / } \\
2018 \text { p., \% }\end{array}$ & $\begin{array}{c}2018 \\
\text { рік }\end{array}$ & $\begin{array}{c}2019 \\
\text { рік }\end{array}$ & $\begin{array}{c}2019 \text { p. / } \\
2018 \text { p., \% }\end{array}$ & $\begin{array}{c}2018 \\
\text { рік }\end{array}$ & $\begin{array}{c}2019 \\
\text { рік }\end{array}$ & $\begin{array}{c}2019 \text { p. / } \\
2018 \text { p., \% }\end{array}$ \\
\hline 1. Зернові і зернобобові & 293,4 & 298,1 & 101,6 & 42,2 & 43,4 & 102,8 & 12372,1 & 12926,3 & 104,5 \\
\hline \multicolumn{10}{|l|}{ у тому числі: } \\
\hline - пшениця & 157,1 & 162,0 & 103,1 & 42,8 & 43,9 & 102,6 & 6717,0 & 7121,1 & 106,0 \\
\hline - ячмінь & 32,6 & 33,5 & 102,7 & 33,0 & 34,0 & 103,0 & 1078,0 & 1140,0 & 105,7 \\
\hline - кукурудза на зерно & 27,6 & 31,8 & 114,9 & 104,3 & 93,3 & 89,5 & 2884,8 & 2962,5 & 102,7 \\
\hline 2. Технічні культури & 114,6 & 132,5 & 115,6 & $\mathrm{x}$ & $\mathrm{x}$ & $\mathrm{x}$ & $\mathrm{x}$ & $\mathrm{x}$ & $\mathrm{x}$ \\
\hline \multicolumn{10}{|l|}{ у тому числі: } \\
\hline 2.1. Олійні культури & 100,8 & 120,6 & 119,6 & 30,5 & 28,0 & 91,8 & 3065,3 & 3379,5 & 110,3 \\
\hline - соняшник & 23,6 & 31,4 & 132,9 & 29,4 & 30,1 & 102,4 & 95492,0 & 944,7 & 135,9 \\
\hline $\begin{array}{l}\text { - ріпак озимий та } \\
\text { кольза }\end{array}$ & 42,4 & 52,0 & 122,8 & 32,2 & 29,6 & 91,9 & 36750 & 1541,6 & 113,0 \\
\hline- соя & 33,7 & 36,0 & 106,8 & 29,6 & 24,6 & 83,0 & 17093,0 & 877,5 & 88,8 \\
\hline 3. Буряк цукровий & 12,2 & 9,2 & 75,9 & 434,6 & 446,0 & 102,6 & 4560,0 & 4117,4 & 77,9 \\
\hline Всього & 420,2 & 439,8 & 104,7 & $\mathrm{x}$ & $\mathrm{x}$ & $\mathrm{x}$ & $\mathrm{x}$ & $\mathrm{x}$ & $\mathrm{x}$ \\
\hline
\end{tabular}

* Джерело: розраховано на основі [2] 
Економічні науки: збірник наукових прачь Луиького національного технічного університету. Серія "Регіональна економіка". Випуск 17 (67). Редкол.: відп. ред. к.е.н., професор І.В. Кривов'язюк. Луиьк: ІВВ Луцького НТУ, 2020. 348 с.

\section{2. Вплив факторів на валовий збір олійних культур}

Послідовність розрахунку:

Загальний індекс валового збору олійних культур:

$$
I_{\mathrm{zar}}=\sum \Pi_{1} \mathrm{Y}_{1} / \sum \Pi_{0} \mathrm{y}_{0}=3379,5 / 3065,3=1,103 \text {, тобто }
$$

загальний приріст валового збору олійних культур становить 10,3\%. Такий приріст обумовлений:

а) впливом зміни зібраної площі на валовий збір олійних культур:

$\mathrm{I}_{\mathrm{B} 3 \Pi}=\sum \Pi_{1} \mathrm{y}_{0} / \Pi_{0} \mathrm{y}_{0}=120,6 * 30,5 / 100,8 * 30,5=1,196$,

б) впливом зміни середньої урожайності на валовий збір олійних культур:

$\mathrm{I}_{\mathrm{B} 3 \Pi}=\sum \Pi_{1} \mathrm{Y}_{0} / \Pi_{0} \mathrm{Y}_{0}=120,6 * 28,0 / 120,6 * 30,5=0,918$, тобто збільшення зібраної площі на 19,8 тис га забезпечило зростання валового збору на 19,6 \%, а зниження урожайності на 2,5 ц спричинило зменшення валового збору на 8,2 \%.

Отже, зростання валового збору зернових і зернобобових культур майже в однаковій мірі обумовлюється як збільшенням зібраної площі, так і підвищенням урожайності. Натомість зростання валового збору олійних культур забезпечується переважно за рахунок залучення додаткових площ до сільськогосподарського обробітку. У першу чергу, це свідчить про екстенсивний шлях використання сільськогосподарських земель Волинської області. Така ж тенденція характерна і для України загалом.

У достовірності зробленого висновку можна переконатись, провівши аналіз динаміки площі збору сільськогосподарських культур за більш тривалий проміжок часу - п'ять років (табл. 2).

Варто зазначити, що у 2019 р. порівняно з 2015 р. площа збору сільськогосподарських культур в Україні зросла на 6,7 \%, а у Волинській області - на 18,7 \%, що є свідченням зростання рівня освоєння i навантаження на сільськогосподарський грунтовий покрив та підвищення імовірності виникнення загроз поширення ерозійних процесів і деградації земельного фонду країни загалом, i Волинської області зокрема. Доцільно акцентувати увагу i на значному збільшенні площ збору 
Економічні науки: збірник наукових прачь Луиького національного технічного університету. Серія "Регіональна економіка". Випуск 17 (67). Редкол.: відп. ред. к.е.н., професор І.В. Кривов’язюк. Луцьк: ІВВ Луцького НТУ, 2020. 348 с.

соняшника та ріпаку. Вирощування таких культур виснажує грунт i призводить до зниження родючості сільськогосподарських земель.

Висновки. Отже, забезпечення позитивної динаміки у сільському господарстві як Волинської області, так і України можливе на засадах сталого розвитку. Для цього необхідно: 1) оптимізувати пропорції між галузями сільського господарства (рослинництво i тваринництво); 2) змінювати структуру посівних площ на користь культур, які забезпечують не лише економічний, але й екологічний ефект; 3) знизити рівень розораності сільськогосподарських угідь для уникнення негативних екологічних наслідків.

Перспективи використання сільськогосподарських угідь пов'язані 3 інтенсивними методами розвитку сільського господарства, зокрема галузі рослинництва. Так зростання валового збору сільськогосподарських культур доцільно забезпечувати через підвищення їх урожайності, що досягається дотриманням сільськогосподарськими землекористувачами науково обгрунтованих систем сівозмін, суттєвим нарощуванням внесення органічних добрив, зміною структури внесення мінеральних добрив, підвищенням технічного рівня обробітку сільськогосподарських земель тощо.

Динамічний розвиток сільського господарства Волинської області сприятиме зростанню зайнятості сільського населення та розв'язанню низки соціальних проблем. 
Таблиця 2

Аналіз динаміки зібраної площі сільськогосподарських культур

в Україні та у Волинській області за 2015 і 2019 роки, тис га

\begin{tabular}{|c|c|c|c|c|c|c|c|c|c|c|}
\hline \multirow{3}{*}{ Культури } & \multicolumn{10}{|c|}{ Площа збору сільськогосподарських культур, тис. га } \\
\hline & \multicolumn{5}{|c|}{ Україна } & \multicolumn{5}{|c|}{ Волинська область } \\
\hline & $\begin{array}{l}2015 \\
\text { рік }\end{array}$ & $\begin{array}{c}2019 \\
\text { рік }\end{array}$ & 2019 p. & $\begin{array}{l}\text { Абсолютне } \\
\text { відхил., +/- }\end{array}$ & $\begin{array}{c}\text { Відносне } \\
\text { відхил., \% }\end{array}$ & $\begin{array}{c}2015 \\
\text { рік }\end{array}$ & $\begin{array}{l}2019 \\
\text { рік }\end{array}$ & $\begin{array}{l}2019 \text { p. / } \\
2015 \text { p., \% }\end{array}$ & $\begin{array}{l}\text { Абсолютне } \\
\text { відхил., +/- }\end{array}$ & $\begin{array}{l}\text { Відносне } \\
\text { відхил., \% }\end{array}$ \\
\hline 1. Зернові і зернобобові & 14640,9 & 15291,9 & 104,4 & 651,0 & 4,4 & 269,7 & 298,1 & 110,5 & 28,4 & 10,5 \\
\hline - пшениця & 6839,5 & 6812,4 & 99,6 & $-27,1$ & $-0,4$ & 145,5 & 162,0 & 111,3 & 16,5 & 11,3 \\
\hline - ячмінь & 2805,2 & 2609,2 & 93,0 & $-196,0$ & $-7,0$ & 33,6 & 33,5 & 99,7 & $-0,1$ & $-0,3$ \\
\hline - кукурудза на зерно & 4083,5 & 4986,9 & 122,1 & 903,4 & 22,1 & 19,1 & 31,8 & 166,5 & 12,7 & 66,5 \\
\hline 2. Технічні культури & 8209,5 & 9129,9 & 111,2 & 920,4 & 11,2 & 89,6 & 132,5 & 147,9 & 42,9 & 47,9 \\
\hline 2.1. Олійні культури & 8093,9 & 8923,3 & 110,2 & 829,4 & 10,2 & 75,5 & 120,6 & 159,7 & 45,1 & 59,7 \\
\hline - соняшник & 5166,2 & 5958,9 & 115,3 & 792,7 & 15,3 & 2,5 & 31,4 & 12,6 разу & 28,9 & 1156,0 \\
\hline \begin{tabular}{|lll} 
- ріпак \\
кольза
\end{tabular} & 671,1 & 1279,2 & 1,9 разу & 608,1 & 90,6 & 25,1 & 52,0 & 2,1 разу & 26,9 & 107,2 \\
\hline- соя & 135,6 & 612,8 & 75,5 & $-522,8$ & $-24,5$ & 7,0 & 6,0 & 76,6 & $-11,0$ & $-23,4$ \\
\hline 3. Буряк цукровий & 237,0 & 221,3 & 93,4 & $-15,7$ & $-6,6$ & 11,3 & 9,2 & 81,4 & $-2,1$ & $-18,6$ \\
\hline Всього & 23087,4 & 24643,1 & 106,7 & 1555,7 & 6,7 & 370,6 & 439,8 & 118,7 & 69,2 & 18,7 \\
\hline
\end{tabular}

* Джерело: розраховано на основі [2] 
Економічні науки: збірник наукових праць Луиького начіонального технічного університету. Серія "Регіональна економіка". Випуск 17 (67). Редкол.: відп. ред. к.е.н., професор І.В. Кривов’язюк. Луцьк: ІВВ Луцького НТУ, 2020. 348 с.

\section{Список бібліографічного опису}

1. Статистична інформація: Національні рахунки URL: http://www.ukrstat.gov.ua/.
2. Сільське
господарство
України
URL

http://www.ukrstat.gov.ua/druk/publicat/kat_u/2020/zb/09/zb_sg_Ukr_2019.pdf.

3. Екологічний паспорт Волинської області URL:

https://voladm.gov.ua/article/ekologichniy-pasport-volinskoyi-oblasti-za-2019-rik/.

\section{References}

1. Statystychna informatsiya: Natsional'ni rakhunky URL: http://www.ukrstat.gov.ua/.
2. Sil's'ke
hospodarstvo
Ukrayiny
URL

http://www.ukrstat.gov.ua/druk/publicat/kat_u/2020/zb/09/zb_sg_Ukr_2019.pdf.

3. Ekolohichny pasport Volyns'koyi oblasti URL: https://voladm.gov.ua/article/ekologichniy-pasport-volinskoyi-oblasti-za-2019-rik/. 